\title{
Pre-pottery Neolithic age spatial planning: The typo-morphology of the first urbanisation with reference to three Akarçay Tepe plaques
}

\author{
Şirin Gülcen Eren \\ Süleyman Demirel University, Faculty of Architecture Department of City and Regional Planning, \\ sirineren@sdu.edu.tr/gulcen8@hotmail.com
}

\begin{abstract}
:
Every civilisation, based on its socioeconomic relations, designs its land regime by using a cadastral system, plans the ways in which its land will be used, and present these through maps or spatial plans. Akarçay Tepe Lined and Marked Limestone Plaques, the use reasons of which are unknown by the archaeology discipline, were originally found during excavations and are on exhibition in Şanlıurfa Museum in Turkey. The plaques have been dated back to the Pre-Pottery Neolithic Age.

This paper aims to present what Plaques from Akarçay Tepe actually refer to and the methodology of determination. It originates from a research study which was commenced in 2017 on the basis of the propositions that these Plaques are in fact, maps and spatial plans showing the land regime and topography at the time they were made. Spatial dimensions of three Akarçay Tepe plaques with reference to technical features are examined on the foundation of the urban planning discipline. The objective here is to make it possible to adjust the findings of an archaeological excavation and to make a contribution as a proposed alternative method for the evaluation of these findings.

The three plaques for which research permission was granted were not related to the cadastral arrangements of Akarçay Tepe, but provide indications of the patterns of other settlements: Birecik, Yeşilözen, and Nizip. The plaques are spatial plans drawn to 1:1000 scale displayed in the form of a 3-D model map. The plaques show the settlement topography, land regime, land use decisions, boundaries of control and settlement and agricultural support systems. Plaques, besides agricultural land pattern display the first typo-morphology of urbanisation of the Pre-Pottery Neolithic Age.
\end{abstract}

Keywords: Land Regime, Akarçay Tepe, Pre-pottery Neolithic, Map, Spatial Planning

\section{Introduction}

Geographies constitute the entirety of the cultural heritage of various civilisations that have been established one after the other for thousands of years. Throughout the history of humanity, the nature and momentum of social relations have brought with them a need to make records of social and spatial relations. If decisions are to be taken in respect of the land regime, the area in question must be designed into cadastral lots and functions must be distributed and registered. Like those of the past, today's civilisations establish land regimes. With the process of individualisation and the development of the sense of ownership, individuals come to draw lines on the Earth in order to protect the land they have laboured on and to determine the boundaries of the ownership or uses of this land. Collectively, the ownership boundaries of lands belonging to people with the same social outlook and principles of life constitute the land regime. The act of setting out boundaries serves as proof of an affinity with the place in question, and aims to guarantee that this affinity, and the associated relations of production and social order, will persist. Patterns, designs and motifs represent spaces with differing functions. However, use is made of the references, lines and shapes of the previous period.

By creating a record of a specific area or property owned, the land regime also has a symbolic aspect and results in a structure which changes only slowly. The land regime can only be changed entirely if the nature of the civilisation and the way in which it is governed are transformed or with natural hazards.

Three-dimensional landscape models, two-dimensional maps, spatial plans and cadastral plans are the instruments which are used to register and demonstrate the forms of affinity with the land. The land regime, shaped by rights to property, should be thought of as paving the way for the social acceptance and position of the land owner. It also makes it possible to calculate the form, nature and amount of productive activity on the land, and consequently the shares to be derived from this production.

In this context, in addition to the land regime formed through the cadastral division of the land, it is also worth mentioning other spatial indicators and signs of ownership such as geoglyphs, petroglyphs (tamgas) and geostamps ${ }^{\circledR}{ }^{1}$. Every civilisation that controls an area or region makes use of a special sign or instrument created 
from a certain material to communicate to society for identifying the boundaries of ownership over the geography in question.

The Lined and Marked Stone Plaques from Akarçay Tepe (Arimura et al. 2000; Özbaşaran et al. 2007, Özbaşaran, 2008; Bozbay, 2009) (Akarçay Tepe Plaques) are findings that need to be examined within this purview. The limestone plaques are on exhibition in the Şanliurfa Archaeology Museum under the description "Akarçay Tepe Stone Plates with Line Patterns". During a visit to the museum in April 2017, spatial dimension of the Plaques was established from the lined designs and sloping structures. They possess the characteristics of a cadastral division of land in the form of a threedimensional land model. The three plaques, which are said to belong to the Pre-Pottery Neolithic Age at least (Özbaşaran 2008; Bozbay, 2009), were then examined on the basis of this proposition, and spatial dimensions are presented in this paper. The aim here is to explain what plaques refer to and how the methodology of determination is.

Other than the conclusive remarks the sections of the paper are ordered as follows: the Akarçay Tepe Plaques study process and research method; plaques as archaeological findings and the settlements to which they appertain and their locations within the settlements.

\section{Research Process and Method}

This paper is based on the technical report prepared by the author and was supported by a review of the literature in the disciplines of archaeology, history, cartography, and urban planning. The research commenced in May 2017, using own resources, based on the prediction that the plaques, since they were discovered during the excavation of the Akarçay Tepe mound (Akarçay Mound, Cort Mound) (Algaze et al. 1994, Arimura et al. 2000:181, Özbaşaran, Molist 2006, Özbaşaran et al. 2007), are a representation of the cadastral order in Akarçay Tepe and its immediate environment. The study makes the assumption that the topography has unchanged greatly since ancient times, and that the settlement pattern carries the marks of past eras.

The paper examines the said archaeological findings from the discipline of urban planning with a multidisciplinary perspective and an inter-disciplinary methodology. The location of the plaques is pertained by superposing plaque plans to current land pattern and measurement correlation is searched for. The plaques are also searched from the angles of cartography, site planning principles, settlement location systematic, agricultural area systematic, pathway systematic, well systematic and exhibition systematic.

Following a series of correspondence, permission was obtained from Şanlıurfa Museum on 2 May 2017 and from the excavation site director on 31 August 2017, to study and publish the three plaques shown in Photograph 1. During pre-analysis stage conducted prior to the museum examination, plaque plans did not yield any sign of a cadastral pattern conforming to the Akarçay settlement (Figure 1) (Coordinates: 36 $55^{\prime} 11.90^{\prime \prime N}$, $\left.38^{\circ} 02^{\prime} 18.31^{\prime \prime} \mathrm{E}\right)$.

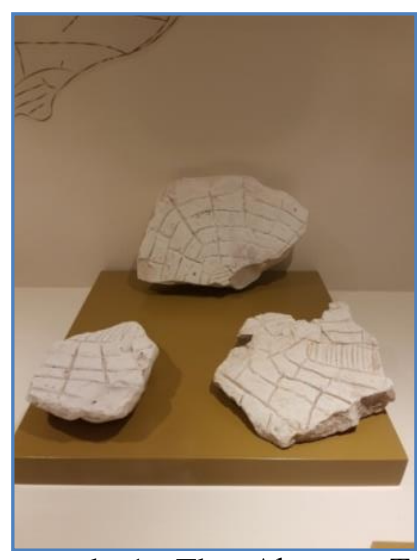

Photograph 1. The Akarçay Tepe Plaques for which Permission to Work and Publish was granted. Plaque A (Centre), Plaque B (Left) and Plaque C (Right). Photographed by the Author, 2017.

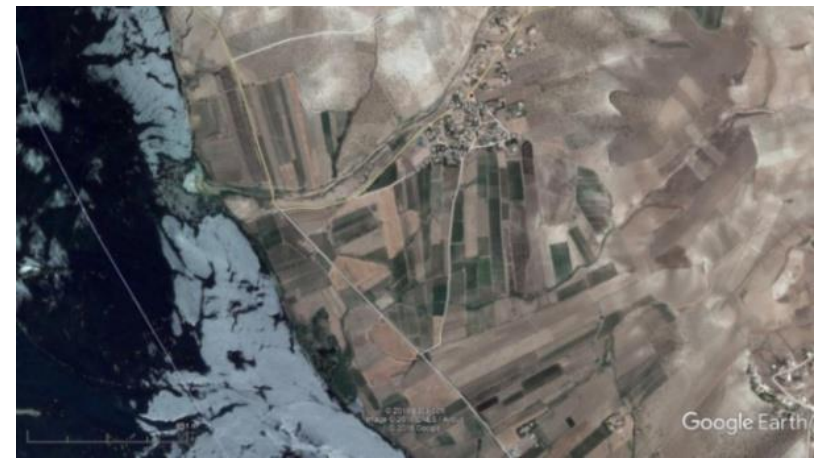

Figure 1. Cadastral Pattern of the Akarçay Settlement. (Source: Google Earth Pro 2018. Altitude: 360m, Height: $3.15 \mathrm{~km})$.

Another large plaque on exhibition in the museum has a certain plaque plan. This plan, when compared to Google Earth images (07 June 2009), resembled the cadastral pattern of the village of Kelekli (Coordinates: $36^{\circ} 54^{\prime} 45.87^{\prime \prime N}, 37^{\circ} 59^{\prime} 36.63^{\prime \prime E}$ ). Some of the parcels of land in the residential area of the habitation of Kelekli coincide with the thick, parallel, clear representation of zones (strip grid plan (grill plan) on the plaque), and their dimensions and proportions conform as well. The settlement pattern in the habitation of Kelekli is made up of parcels arranged, as far as the lie of the land permits, in lines and demarcated by narrow streets or building or garden walls. Figure 2. Photograph 2. This type of plan still exists in the region, particularly in the older textures of towns and in rural settlements that have relatively little interaction with the outside world.

It is found out that the plans on the plaques are designed in such a way as to identify agricultural and settlement areas by using different motifs. Photograph 3. In short, Plaque D played the key role in determining which settlements these plaques belong to. Because of the similarity between this configuration and the hill-top linear compositions occurring on the plaques, this strip grid motif was taken in the analysis to represent human settlements (rows of lots). 


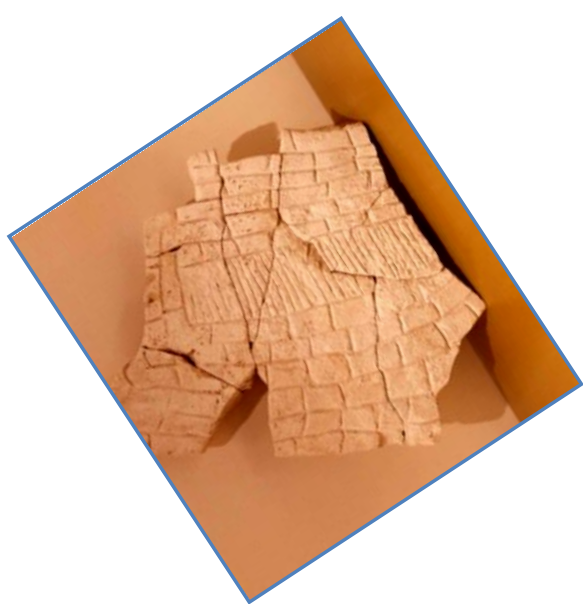

Photograph 2. The Plaque D (Kelekli Plaque). Photographed by the Author, 2017.

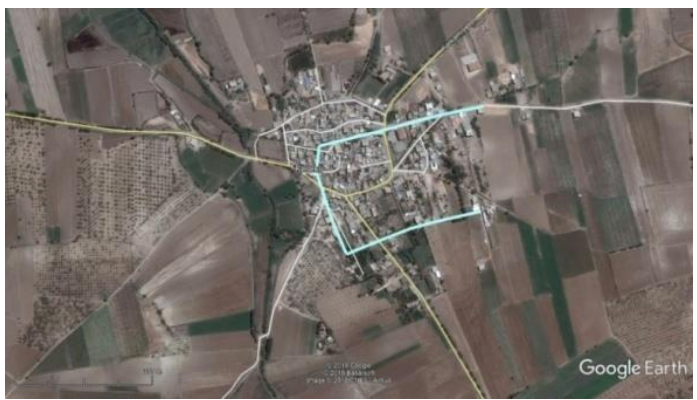

Figure 2. The Kelekli Settlement and a Comparison of its Housing Pattern to the Plaque D settlement area. (Source: Google Earth 2018 Pro. Viewed on 26.01.2018) Drawn by the Author, 2018.

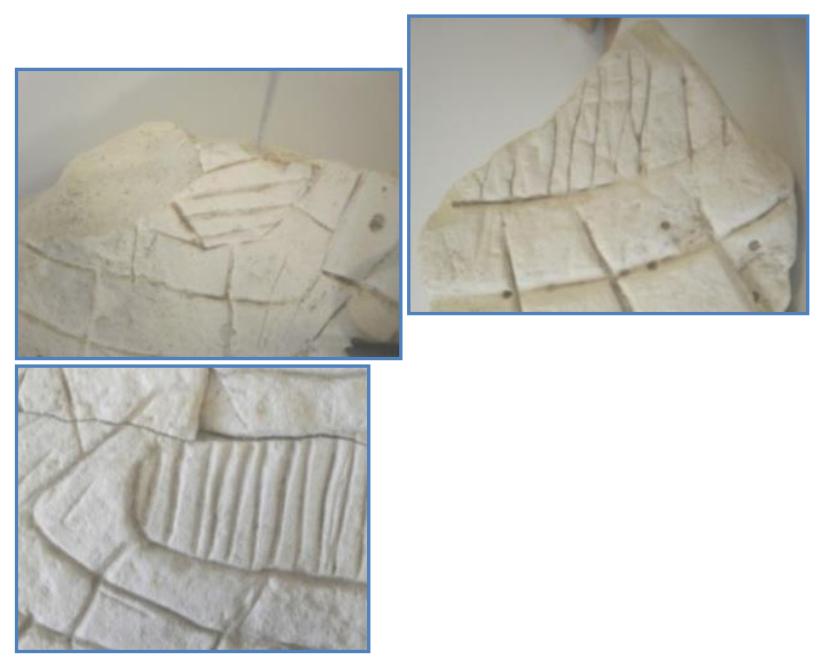

Photograph 3. a, b, c. Examples of Settlement Area Motifs. (Plaque A (top left), Plaque B (top right), and Plaque C (bottom)). Photographed by the Author, 2017.

Permission was sought to examine the Plaque D (Kelekli Plaque), but this could not be obtained. Kelekli is near the River Euphrates and is the settlement aligned with (immediately across the Euphrates from) Akarçay Tepe. It is at a crossroad on the Birecik-Karkamış and NizipAkarçay Tepe routes. It is on the main access route from Nizip to Suruç. The shortest crossing of the Euphrates is between Kelekli and Akarçay. Figure 3.

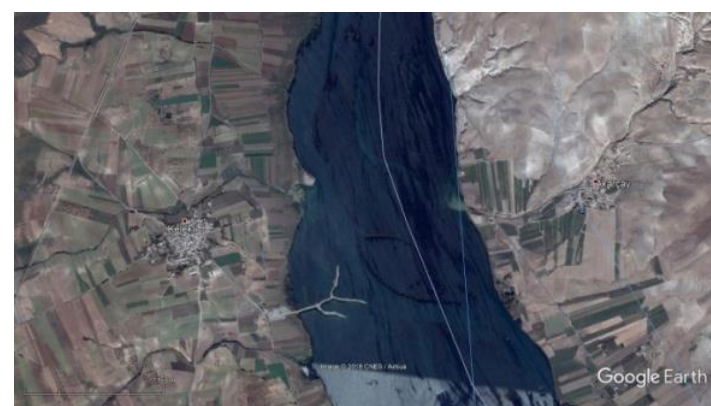

Figure 3. Akarçay and Kelekli and their Relationship to the River Euphrates (Source: Google Earth Pro 2018. Height: 5.43km. Viewed on 20.10.2013).

The three plaques were measured, and their plans were drawn at the Şanliurfa Museum on 18 December 2017. Notes were taken on the technical features and the means of measurement and representation. The measurements may have a partial margin of error of $\pm 0.1 \mathrm{~mm}$. In measuring plaques' plans, the centres of the blocks were generally taken as reference points. Straight edges in the case of lines giving definite results were also noted. The pathway widths were measured separately. Damaged surfaces and dimensions were shown. Some distinctive disruptions were found at the subsequent examination stage to be references that describe certain characteristics of the land, such as river banks, rocks or the courses of streams (Photographs 4-6. Figures 4-6).

Plaque plans are superposed to the cadastral and urban patterns of today. For the analyses of places, the Google Earth Pro programme views (between January 2017 and March 2017) and official cadastral plans were used. Plaque plan measurements are corresponded with the pattern measures. Data on the topography of the alternative areas identified were compared using the ESRI Topography Map. Two excursions were made in 2018. In the latter field study; preliminary fact-finding control was done in situ.

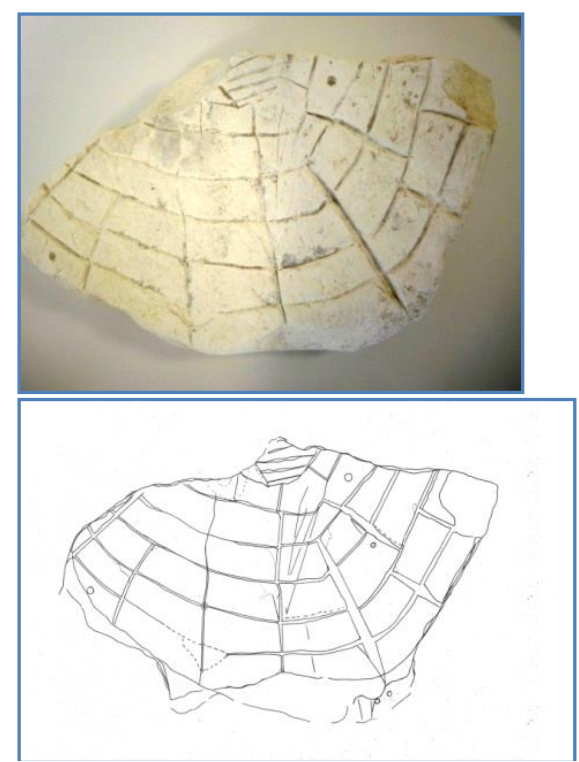

Photograph 4. Plaque A. Photographed by the Author, 2017.

Figure 4. Plan of Plaque A. Drawn by the Author, 2017. 

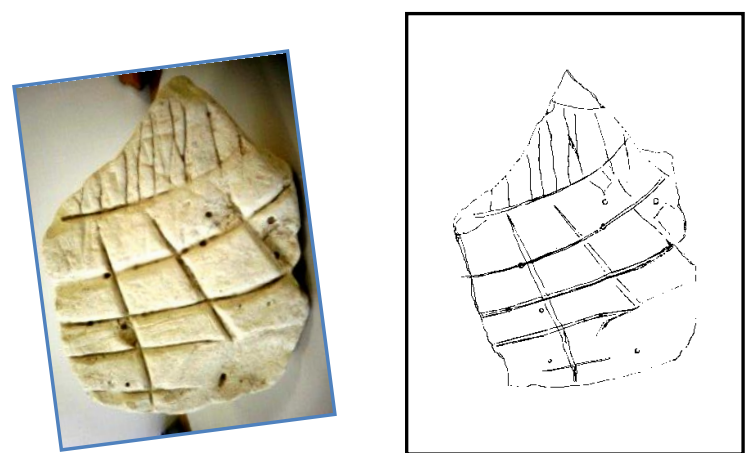

Photograph 5. Plaque B. Photographed by the Author, 2017.

Figure 5. Plan of Plaque B. Drawn by the Author, 2017.

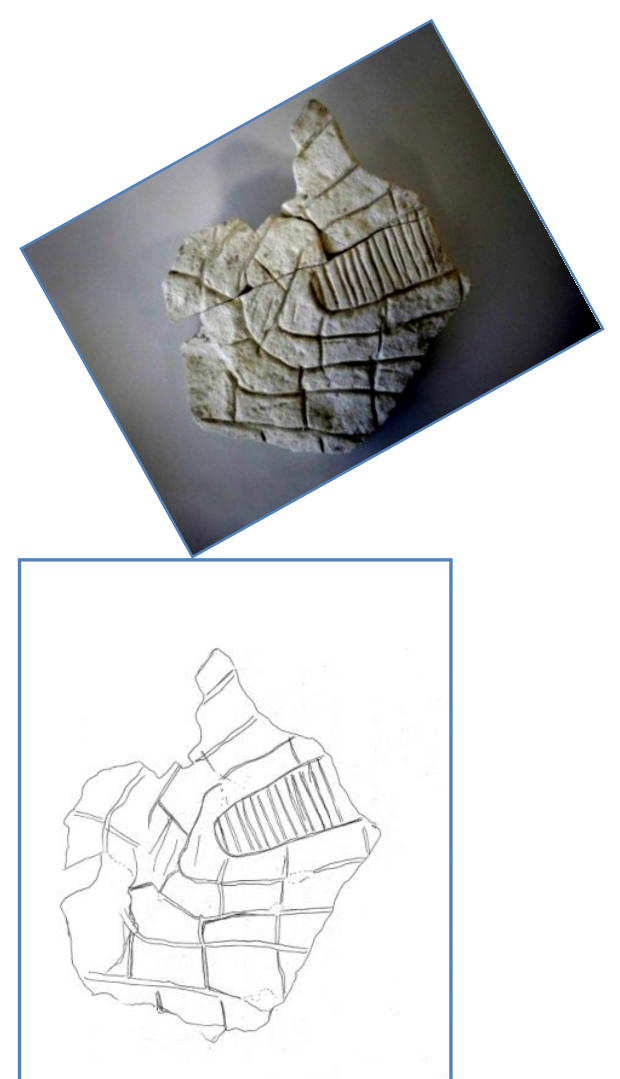

Photograph 6. Plaque C. Photographed by the Author, 2017.

Figure 6. Plan of Plaque C. Drawn by the Author, 2017.

As the Kelekli Plaque was known to refer to a place other than Akarçay, it was assumed that the plaques under examination could be representations of other settlements. And, as the wheel had not yet been invented, these must be within a few days' walking distance of Akarçay Tepe. At this stage of the analysis, it was envisaged that a person could walk for 10 hours and cover $11-13 \mathrm{~km}$ at most in one day, including Syrian territory. Walking axes and distances between regional settlements were used to determine the study area.

The study area was extended to approximately $13,646 \mathrm{~km}^{2}$ (Figure 7). It encompassed narrow valleys that lead from four directions towards the two banks of the River Euphrates and plains leading down to the river and to
Akarçay Tepe. The principles of settlement site selection and the relationship between settlements and routes were determined.

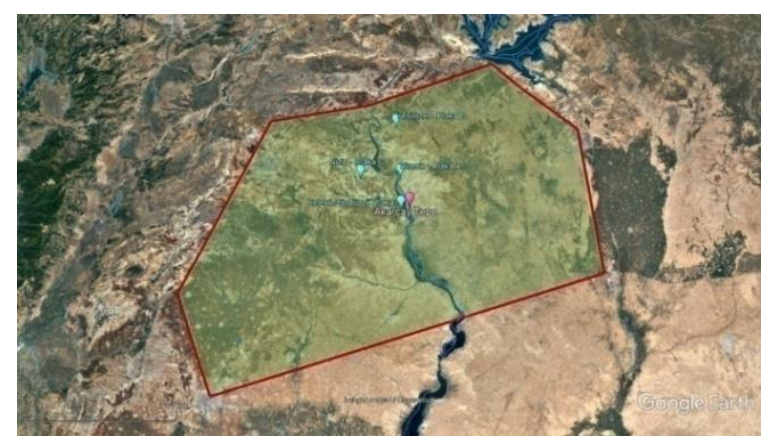

Figure 7. Research Area (13,646 km2) (Source: Google Earth Pro 2018, Viewed on 16.01.2018). Drawn by the Author, 2018.

The main inputs for identifying the settlement locations within the region under research were the modelling of the plaques, the current topography, plaque design and pattern, the current cadastral pattern, settlement pattern, and the transport axes considering the means available at the time. The form and direction of the plaques, the direction of inclination, the number and dimensions of the cadastral divisions, and the location of the settlements were the other matters taken into account. Alternative zones were identified. The area of land with which the dimensions of the plaque coincided, and which yielded an equal coefficient for the entire plaque, was accepted as the exact location.

Since some parts of the land regimes of earlier periods have been preserved unchanged, their hereditary traces can be observed. The analysis of plaques is based on these traces like lot lines, street lines, property boundaries, topographic features. It has been determined that the systematic elements of the use of land at the time the plaques were made, such as paths, lot borders, residential areas, agricultural areas and wells, are presented on the plaques. The ways in which these distinctions are shown, together with the topography, define the spatial characteristics of the plaques. Designs on the plaques also present the patterns and borders (valley floors where slopes terminate, or geographical thresholds) of the human settlements and agricultural areas, and indicate how they relate to the topography.

The round hollows identified on the plaques can be regarded as representations of the water wells or irrigation systems that were a vital necessity for the settlements and agricultural lands of the agricultural communities. The relationship of the wells with the vertical and horizontal lines of the parcels of land gives the impression that the pattern lines may be for irrigation and paths. In the field study of 2018 , it is found that several presentations thought to be wells are still in their locations and are still functioning.

In order to find out the scales of the plaques, the plaque patterns and cadastral patterns of today were superposed and plaque measures and existing pattern measures are compared. The map scales were calculated for each of the 
plaques separately (See Eren (2018a) for the scaling methods). The measured plaque pattern and the pattern existing on the land today were also compared in an effort to find the same common coefficient as a second way of control. The scales of the plaques were found as to be 1:1,000 (Eren, 2018a).

It is thought that it may be possible to identify the vantage, final adjustment and reference points through a mapping application study to be conducted in situ.

The following section deals with the narrative of the Akarçay Tepe Plaques from the point of view of the discipline of archaeology.

\section{Akarçay Tepe Mound and Plaques}

The Akarçay Tepe Lined and Marked Limestone Plaques were found during the excavations which have been going on at the Akarçay Tepe Mound since 1999. The Mound is located in the Lower Euphrates Basin (Çelik 2008:13) on a peak with an altitude of 360 metres. It is situated $15 \mathrm{~km}$ South of the district centre of Birecik in the province of Şanliurfa. The mound is also situated at the crossing point of the Gaziantep-Nizip-Ayn-el ArapSuruç-Şanlıurfa, Nizip-Akçakale and Birecik-KarkamışJarablus axes. The Mound has been inhabited continuously for 2,000 years (Balkan-Atl1, Özbaşaran TAÇDAM, 2002).

There are 295 limestone plaque pieces (Bozbay, 2009:141) in total. Besides those found in soil used for filling, some had been used as building stones in walls and foundations (Özbaşaran 2008:835; Bozbay, 2009:61, 142). Most of the plaques were discovered in the excavation plan square number 27 (S,T,U,V) and particularly in the open area like a courtyard (corresponding to $27 \mathrm{~T}$ and U) (Bozbay, 2009:142). A single plaque was found inside the structure, on the floor in building $\mathrm{T}$ among broken piece of a stone container and a stone ball like a dead present (Bozbay, 2009:100, 143).

According to Özbaşaran (2008:833-834), the plaques are made up of shapes "depicted" by means of scraping or etching, the shapes on the limestone samples are parts of a single "picture", and their function is unknown. Özbaşaran (2008) states that the plaques discovered do not include whole or completable pieces, that the motifs drawn on them have not been encountered among other findings and that all these "marked limestone" pieces of at least 9,000 years old are intended to express the same thing. They may have special use and functions in the previous layers (Bozbay, 2009:143-144). Özbaşaran (2008:837) remarks that they might be pieces of a game stone or the product of some completely different symbolic narrative. For Bozbay (2009:142), their design resembles a spider web.

Özbaşaran (2008:834) states that the similarity with examples published under the name of "incised stones" or "plaquettes décorées" is limited to the choice of raw material and the etching technique. Examples similar to those found at Akarçay Tepe, which have been discovered at the Southern Levant Pre-Pottery Neolithic Age settlements of Tell Aswad, Munhata and Wadi Jilat
7 , are small plaques of not more than $10 \mathrm{~cm}$, and reflect a different set of ideas, tastes or beliefs (Özbaşaran, 2008:834). She (2008:834) further points out that the inscribed surface find from Tell Turlu (Şehzade Höyük, Nizip), a location close to Akarçay Tepe, is alike in terms of materials and manner of production (See Photographs 6-7 of Özbaşaran (2008:837)).

The three plaques which were examined had designs drawn on only one face. The undersides were observed to have been shaped for the purpose of exhibiting on a stand (Photograph 7). Plaque B has features both for holding and for resting on a stand. The shaping of Plaque B by hand (See Nowell (2017)) is known as a property of the Upper Palaeolithic Age (Photograph 8). The other two plaques have been shaped so as not to slip from the stand system.

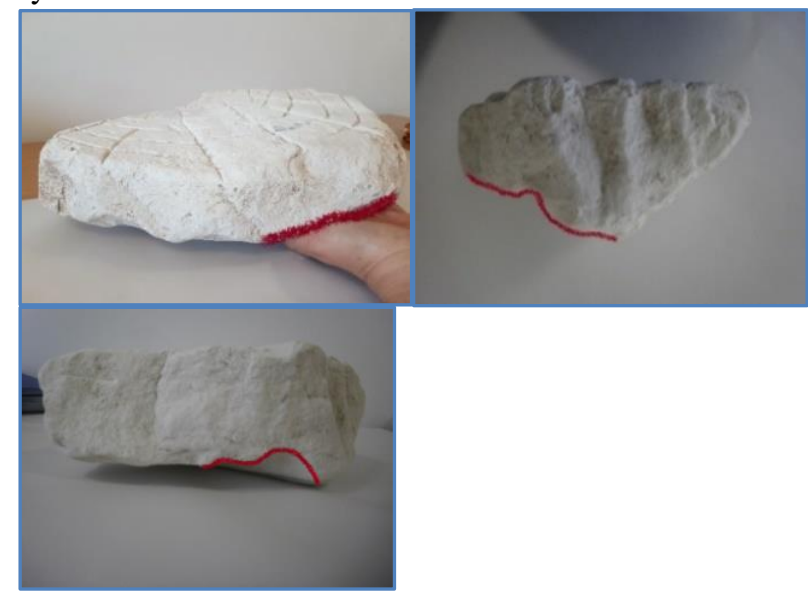

Photograph 7. a., b., c. Details of How the Plaques are Shaped to Rest on Stand. Photographed by the Author, 2017.

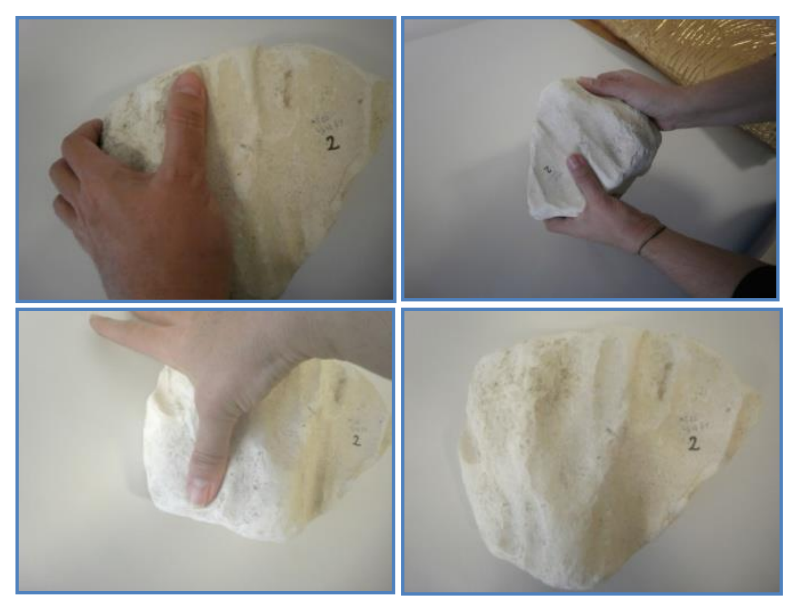

Photograph 8. Plaque B, Details of Parts Shaped by Hand in Two Different Directions and Finger-Fluting. Photographed by the Author, 2017.

The settlements and locations to which the Akarçay Tepe plaques belong are presented in the next section.

\section{Settlements and Locations to which the Plaques Appertain}

Land regimes of today are made up of the cadastral patterns of various civilisations superposed on one 
another. The boundaries of individual properties and the overall land regime or urban texture, which is made up of different properties in the same period, cannot change completely, since they draw on the land regimes of the preceding periods. Of course, once the land regime has been established, some of the existing properties in any area may undergo changes based on renewal schemes or other transformative practices. The immutability of the existing order and settlement pattern is greatest in those places which are removed from the influences of civilisation, or where its progress is slower.

A good example of a settlement with a texture that has not changed for thousands of years is Iznik (Figure 8). There have been changes since ancient times in the basic spatial data pertaining to the region under study. It has been found out that these changes may not be so drastic so as to destroy the previous cadastral pattern or alter the topography.

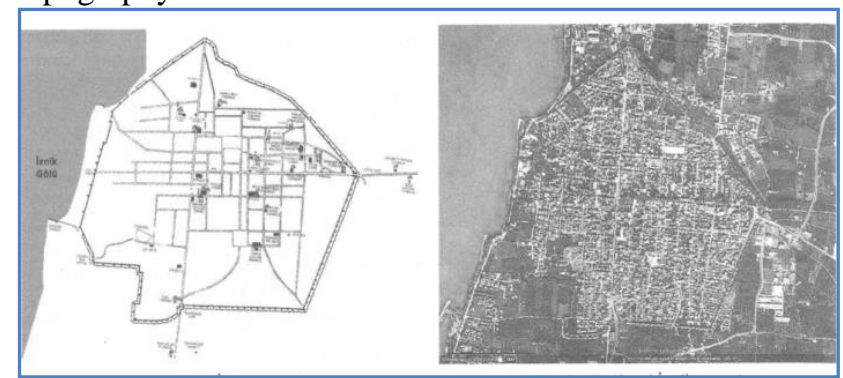

Figure 8. İznik, a. The Roman City, b. The City Today (Source: Ersoy, 2012:146).

The Akarçay Tepe Lined and Marked Stone Plaques studied belong to specific sections of the settlement pattern in the urban areas of the today's settlements of Birecik in the case of Plaque A, Yeşilözen in the case of Plaque B (AT 02261169 2) and Nizip (237) in the case of Plaque $\mathrm{C}$. The numbers of agricultural lots and housing lots on these plaques is given in Table 1 .

\begin{tabular}{lcc}
\hline PLAQUE & $\begin{array}{l}\text { No. of } \\
\text { Housing Lots }\end{array}$ & $\begin{array}{l}\text { No. of } \\
\text { Agricultural Lots }\end{array}$ \\
\hline Plaque A & 4 & 31 \\
Plaque B & 10 & 15 \\
Plaque C & 15 & 28 \\
\hline
\end{tabular}

Table 1. Numbers of Lots by Type of Land.

Most of the historical paths or geographic features within a settlement match the design on the plaques. Although still in use today, some paths or lots indicated in the drawings on the plaques were found to have disappeared due to the way the settlement pattern has developed to. In other cases, these lines had come to correspond with the edges of rows of houses or gardens, due to filling in streets by housing or housing by roads. As areas depicted as agricultural areas are now occupied by roads, housing or other urban facilities, not every boundary line on the plaques corresponds to present-day paths or roads.

The following paragraphs contain findings related to plaque settlements and to their location within this settlement:

\subsection{Plaque A - Birecik}

Plaque A (Birecik Plaque) has $16 \mathrm{~cm}$ width and $19.5 \mathrm{~cm}$ length. Its widest point is $21 \mathrm{~cm}$ across. It belongs to Birecik settlement $\left(37^{\circ} 01^{\prime} 43.41^{\prime \prime} \mathrm{N}, 37^{\circ} 58^{\prime} 50.95^{\prime \prime} \mathrm{E}\right)$. The settlement is to the North of Akarçay Tepe and $13 \mathrm{~km}$ away as the crow flies. The plaque represents the pattern of a settlement situated at an altitude of $380 \mathrm{~m}$. The bottom altitude of the Plaque is $363 \mathrm{~m}$. The slope of the area is $9 \%$.

Plaque $\mathrm{A}$ is on a peak and a West-facing ridge sloping down from this peak to the River Euphrates, with a connection today to the old Urfa road. The residential zone shown on the plaque is situated on a piece of higher ground which is climatically protected and strategically defensible (Figures 9-10, Photographs 9-10). A number of similar land regimes have existed in periods previous and subsequent to the period of the settlement pattern shown on the plaques (Eren, 2018a; 2018b; 2018c).

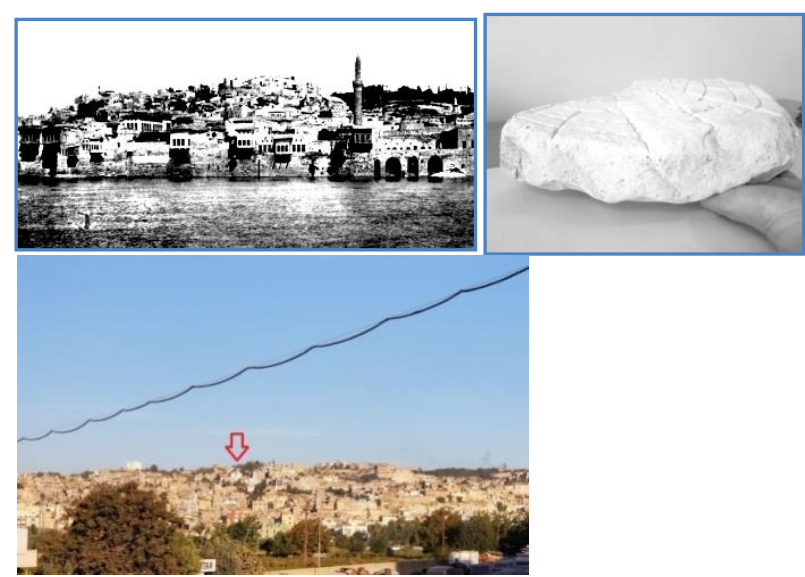

Photograph 9. The Plaque A (Birecik Plaque) and its location in the city.

a. An old picture of Birecik (Source: https://www. bireciktso.org.tr/tr/foto-galeri/eski-resimlerde-birecik/

[Date of access: 19.01.2018]).

b. Plaque A. Photographed by the Author, 2017.

c. Birecik and the location where Plaque A is situated. Photographed by the Author, 2018.

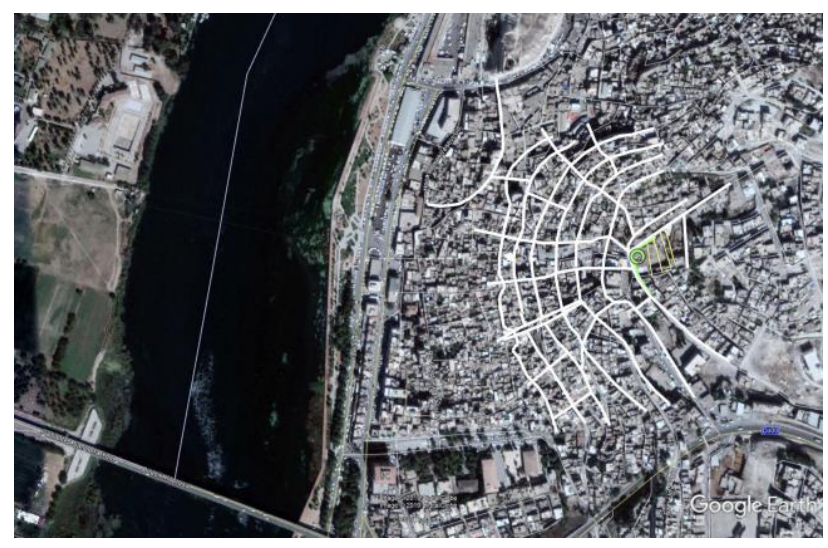




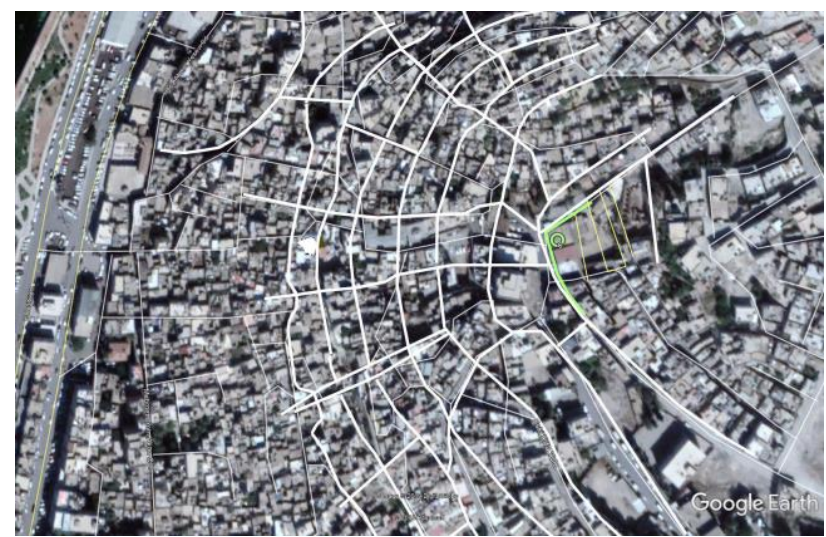

Figure 9. Situation of Plaque A a. Situation of Plaque A in Birecik and modern topography (Source: Google Earth Pro 2018. Author's Drawing, 2018. Eye Level: 855m) b. Situation, closer view. Unscaled.

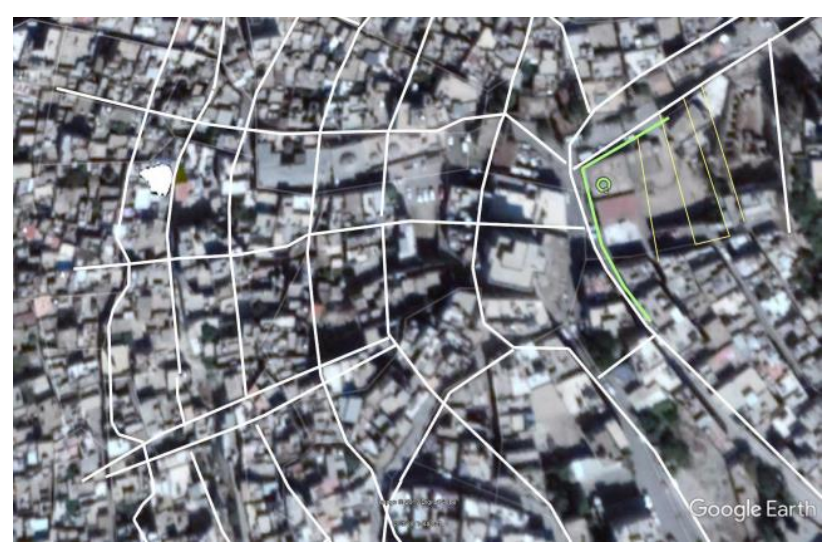

Figure 10. Situation of Plaque A. (Green circle points the corner of the plaque settlement) (Source: Google Earth Pro 2018. Author's Drawing, 2018. Eye Level: 633m) closer view. Unscaled.

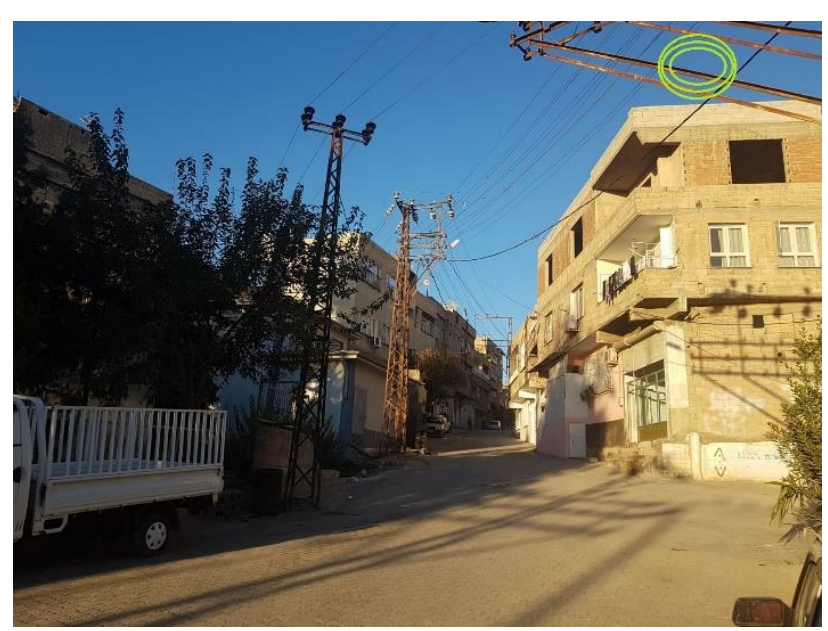

Photograph 10. The vertical form and the corner where the settlement area starts (green circle points the corner). Photographed by the Author, 2018.

In Birecik, several wells could be checked on the field due to security reasons. Among the checked wells, Well
A which is closed today, was once the main clean water source of the city. Photograph 11.

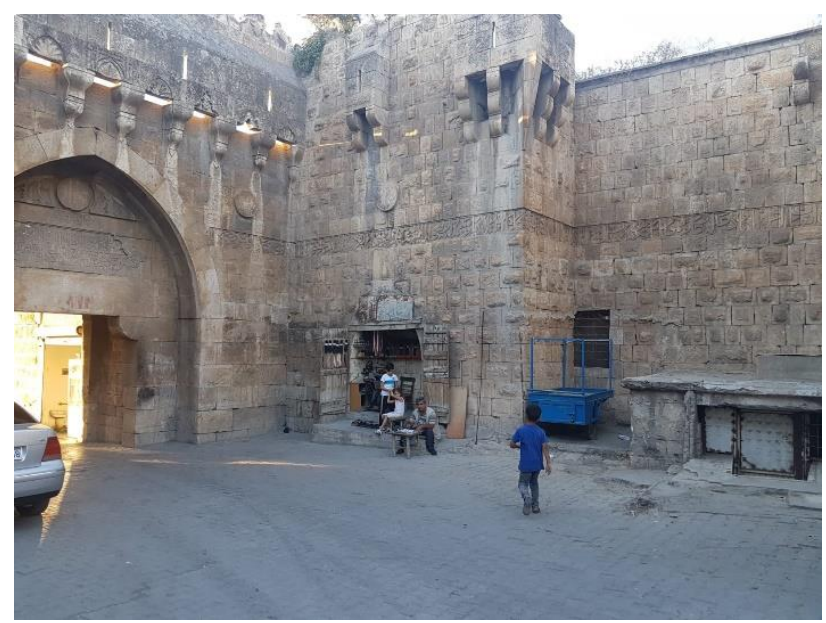

Photograph 11. The Urfa Gate (Left) and the Well A (right). Photographed by the Author, 2018.

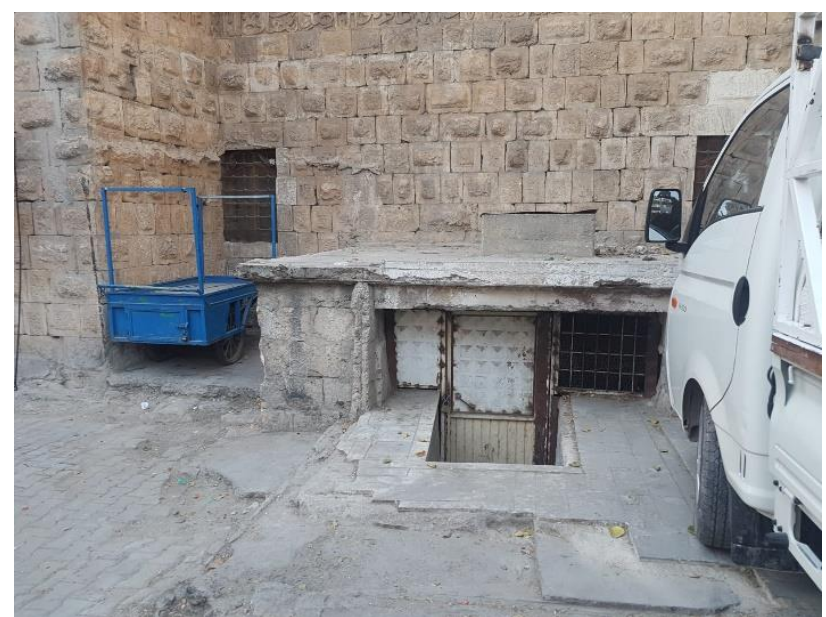

Photograph 12. The Well A (right). Photographed by the Author, 2018.

English (1968) has studied the underground-tunnel wells (qanats) in the south of Kirman, Iran. He states that the wells are linked in rings, and that this is a practice used in a dry, upland basin. The Assyrian cities and caravans on the banks of the River Tigris are known to have been particularly dependent on wells (English 1968:175). The same can be stated for this settlement on the bank of the Euphrates River. However; the relationship of holes on the plaques (Photograph 13) with systems like the qanats irrigation system (the counterpoised sweep (shaduf)) or the Persian Wheel (dulab) spoken of by English (1968) and their relation to Plaques' water systematic needs to be investigated separately. 


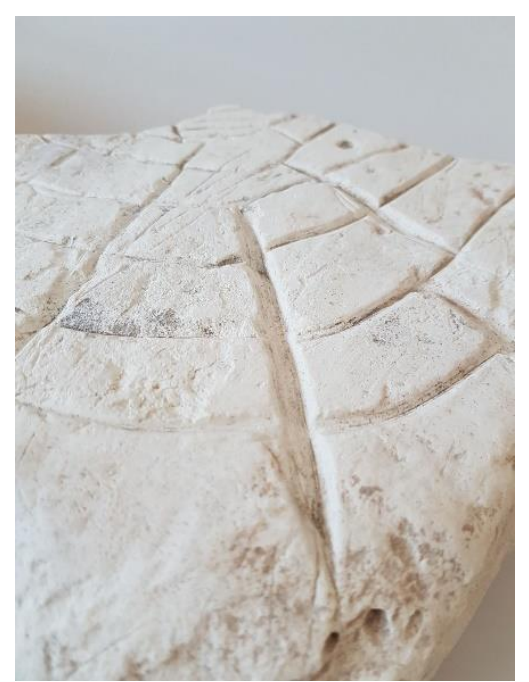

Photograph 13. An example of underground-tunnel wells of the Plaque A on the side of the Euphrates River. Photographed by the Author, 2017.

\subsection{Plaque B (AT 02261169 2) - Yeşilözen}

Plaque B (Yeşilözen Plaque) is the smallest of the pieces examined. It measures $19.6 \mathrm{~cm} \times 14.6 \mathrm{~cm}$ at the maximum and $12.5 \mathrm{~cm} \times 12.5 \mathrm{~cm}$ at the minimum. Plaque $\mathrm{B}$ bears the marks of sound workmanship and of shaping by hand. By comparison with the other plaques, there are clearer signs of the use of a ruler on the upper surface during the etching.

Plaque B belongs to Yeşilözen (37²1'36.47"N, $37^{\circ} 57^{\prime} 21.30^{\prime \prime E}$ ) (Figure 11). This settlement is North of Akarçay Tepe and $33 \mathrm{~km}$ away as the crow flies. Its Southwest access stretches towards Birecik and the Euphrates River and its Southeast axis towards the settlement of Suruç. This Plaque represents a settlement pattern at an altitude of $615 \mathrm{~m}$. Plaque B belongs to the area that is located between the peak at the top and Pınarbaşı Road. The slope of the area of the plaque is $22 \%$.

This point is a geographical entry gate leading from the hilly region in the North to the Southern region, and contains traces of the Palaeolithic Age. Yeşilözen is located on a crossroad. Harmankaya and Erdoğu (2002:20-21) states that cultures of the Euphrates Valley, or which used this valley as a natural pass, were able to reach the upper section of the river. This point is also a route crossing for game animals (Photograph 14).

From the location of the settlement, it has been determined that at the time the plaque was made the settlement must have been hidden behind the western bend of the hill. Those approaching this geographical gateway from the North or passing from the Valley on the east (Halfeti-Şanlıurfa road) would not be able to see the settlement. It might also be suggested that the settlement was positioned according to the climatic conditions and shielded from harsh North winds. Although the roads are towards south to north, the settlement is located on the western slope. The road climbs to the castle on hilltop from this location.
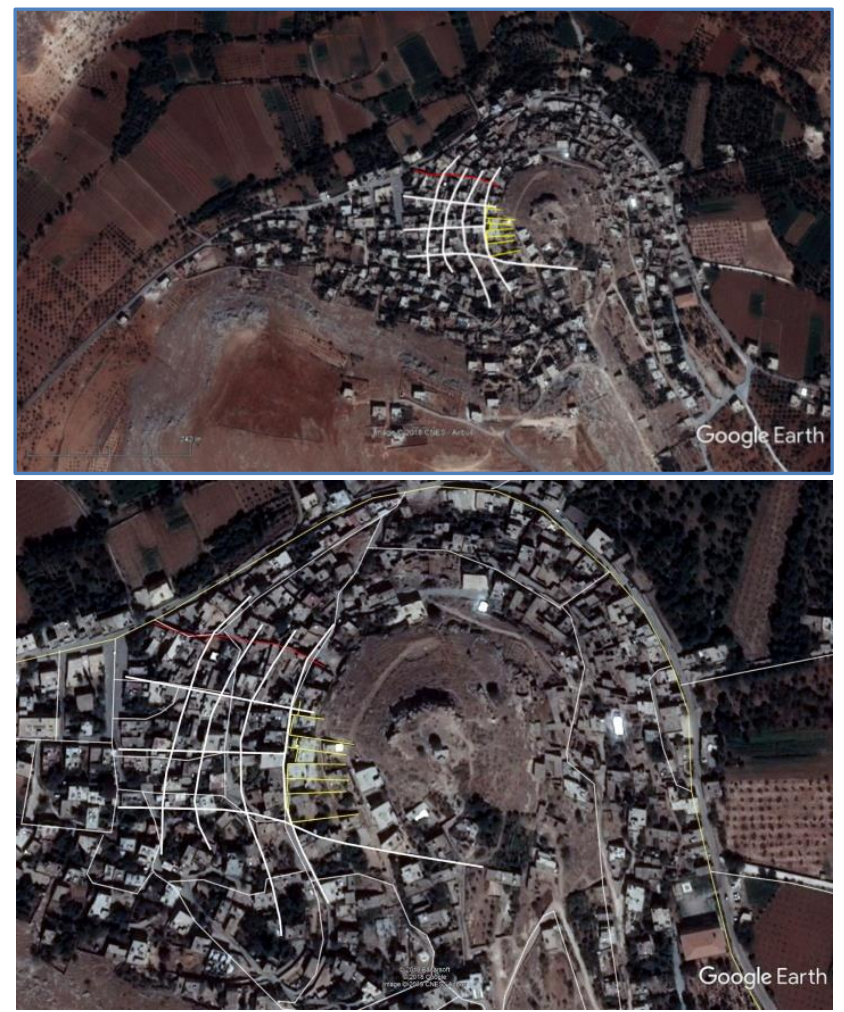

Figure 11. Situation of Plaque B a. Situation of Plaque B in Yeşilözen (Source: Google Earth Pro 2018. Author's Drawing, Eye Level: $1.34 \mathrm{~km}$ ) b. Situation of Plaque B. 2018. Closer view. Unscaled.

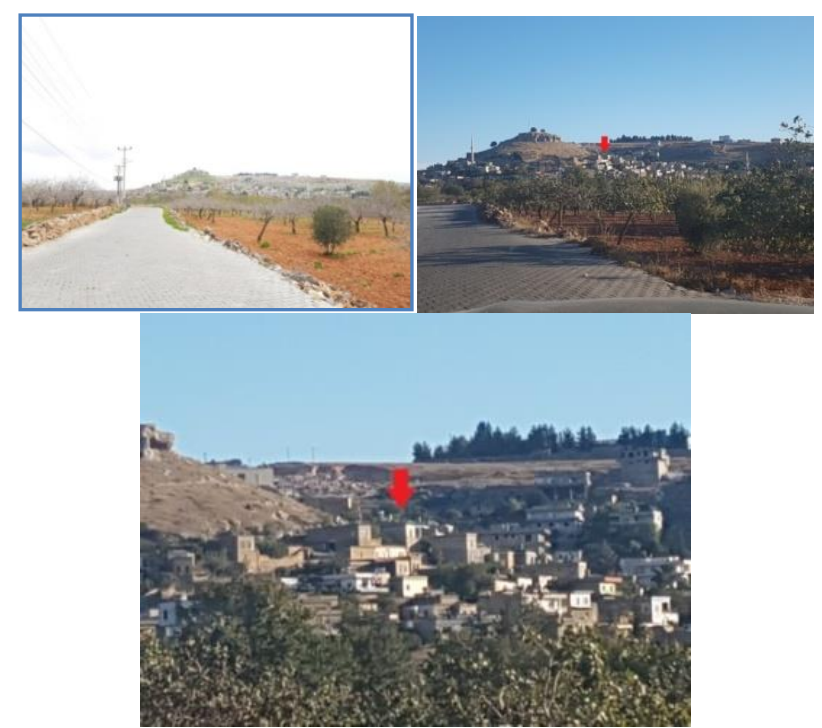

Photograph 14. Yeşilözen. Photographed by the Author, 2018. a. View from the North towards the South from the Yeşilözen-Halfeti Road. b. Closer view towards the South from the Yeşilözen-Halfeti Road. c. The settlement section the Plaque C plan overlaps. 
An analysis of the plaque holes indicated that the round hollows were the reference points of a certain system. In order to link the hollows to one another, straight lines were drawn from their centre points, resulting in triangles (Figure 12, Photograph 15). It was determined that the method of measurement by triangulation used in topographical engineering computer programmes today was applied to the plaques in a simple and systematic way. This method makes it possible to calculate angled gradients, areas and locations.

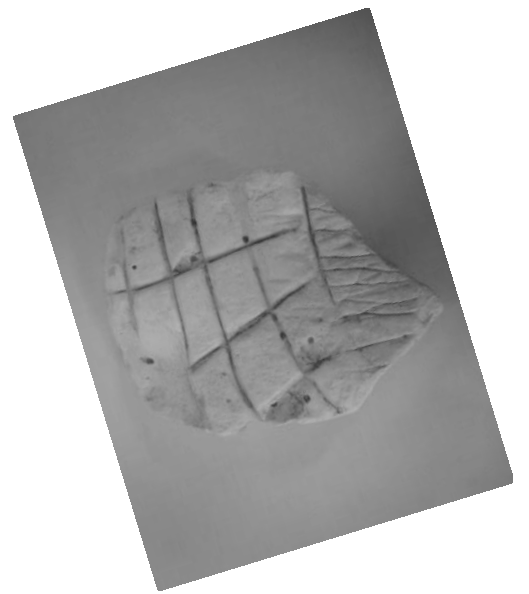

Photograph 15. Plaque B (Yeşilözen). Photographed by the Author, 2017.

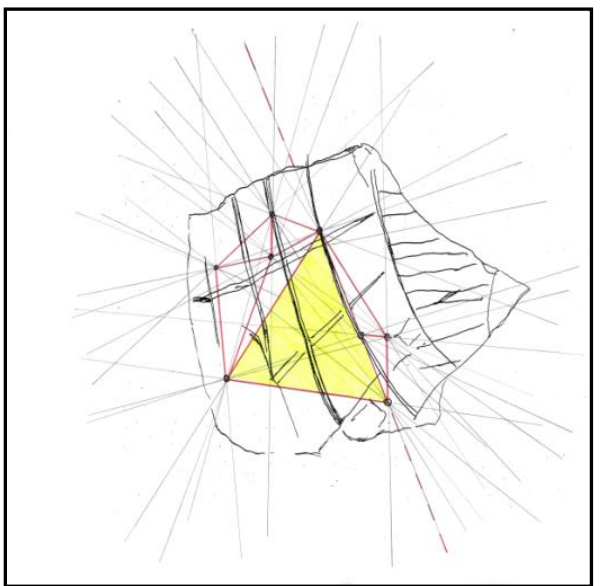

Figure 12. Plaque B Well System and Triangulation. Drawn by the Author, 2018.

In the field study of 2018 , it is found that most of the wells presented on the plaques are currently inside the gardens of private properties. As the General Directorate of Water Works has closed the spring that feeds the settlement, these wells of $4 \mathrm{~m}$ deep become dried. As a result, most of them were destroyed by the locals for security reasons or were turned into sewerage wells.

\subsection{Plaque C (237) - Nizip}

Plaque C (Nizip Plaque) is darker in colour than the other stones (Photograph 16). The dimensions of Plaque $\mathrm{C}$ are
$28.5 \mathrm{~cm} \times 23 \mathrm{~cm}$ at the maximum and $17 \mathrm{~cm} \times 15 \mathrm{~cm}$ at the minimum. Plaque $\mathrm{C}$ belongs to Nizip $\left(37^{\circ} 00^{\prime} 35.69^{\prime \prime} \mathrm{N}\right.$, $\left.37^{\circ} 47^{\prime} 13.30^{\prime \prime E}\right)$ historical city section which is also a registered archaeological site (2008).

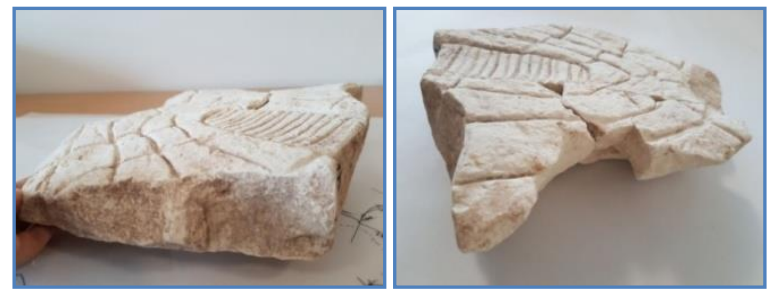

Photograph 16. a.,b. Plaque C, Photographed by the Author, 2017.

The settlement of Nizip is situated to the Northwest of Akarçay Tepe, $23 \mathrm{~km}$ away as the crow flies, at an altitude of $490 \mathrm{~m}$. The area slope is $13 \%$ on average. It is on the Suruç - Akarçay - Gaziantep, Aleppo - Rumkale and Şanliurfa - Birecik-Gaziantep axes. Plaque C is the best example of the complete correspondence between the streets of the settlement and its historical paths as well as plaque design and property lines of today. The site shown on Plaque $\mathrm{C}$ is an area defined by the bank of the the Nizip Brook on the west. It is surrounded by the streets of Pazar Sokak, Cumhuriyet Caddesi, Çay Sokak, Ziyaret Sokak, Değirmen Sokak and Hamam Sokak (Figures 1314).

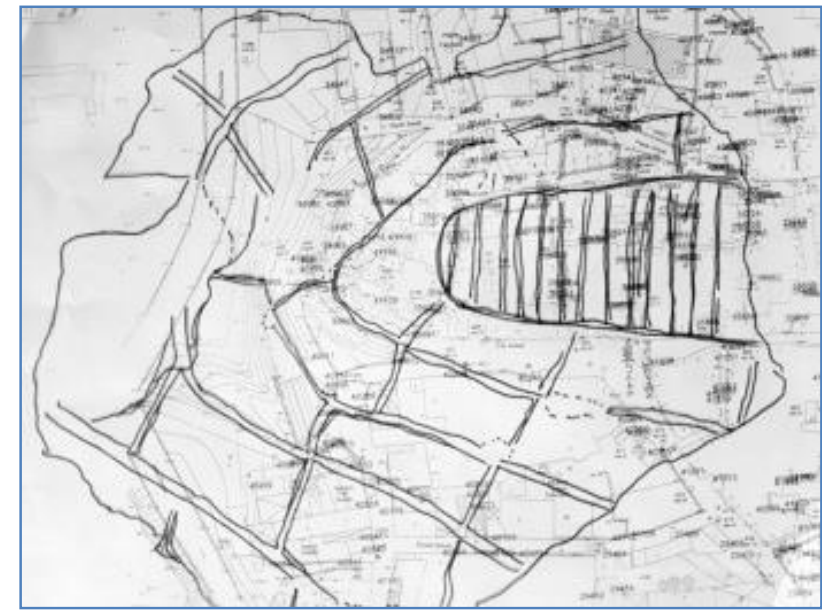

Figure 13. Plaque C Plan Superimposition on Topographic Map of 2015.

The distinctive feature of this plaque is that the residential area at the topmost point is in the form of a hollow (Photograph 16). The hilltop is the origin of application and from here the height difference starts. The settlement section on top of the plaque is lower than the sides. Today this hollow form is distinguishable in $490 \mathrm{~m}$ plain. The hilltop is at $495 \mathrm{~m}$ altitude. The height difference starts from the hilltop (Photograph 17). The courtyard designed at the hilltop is currently a social gathering 
space. This space corresponds to the first round settlement strip and is thought to be used with the same purpose at the time plaques were made (Photograph 18).

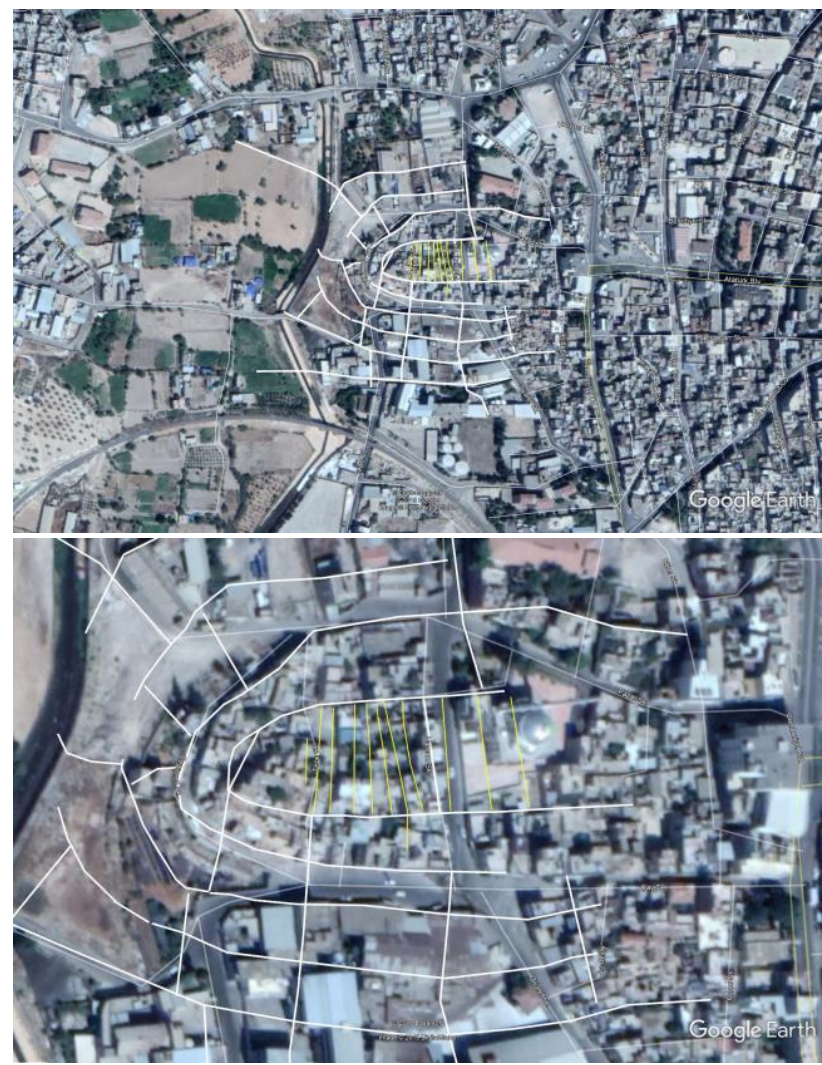

Figure 14. Situation of Plaque C a. Situation of Plaque C in Nizip (Source: Google Earth Pro 2018. Author's Drawing, the Eye-level: $1.34 \mathrm{~km}$.) b. Situation of Plaque C. Closer view. Unscaled.

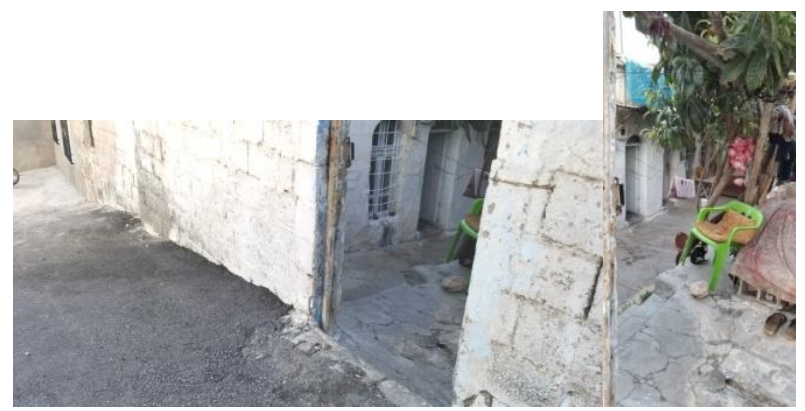

Photographs 17 a., b. Height difference from the hilltop (Photographed by the author standing at the hilltop, 2018).

Today Nizip Brook is rehabilitated. When the plaque plan is superimposed to modern topography, the interpretation of the topography and other spatial inputs of the Plaque plan becomes apparent. Shore of the stream, direction of the contour lines, and shoreline is coherent with the curvilinearity of the riverbed.

There were no holes in Plaque $\mathrm{C}$, which could be the result of closeness to springs and the Nizip brook (a lowlying settlement area).

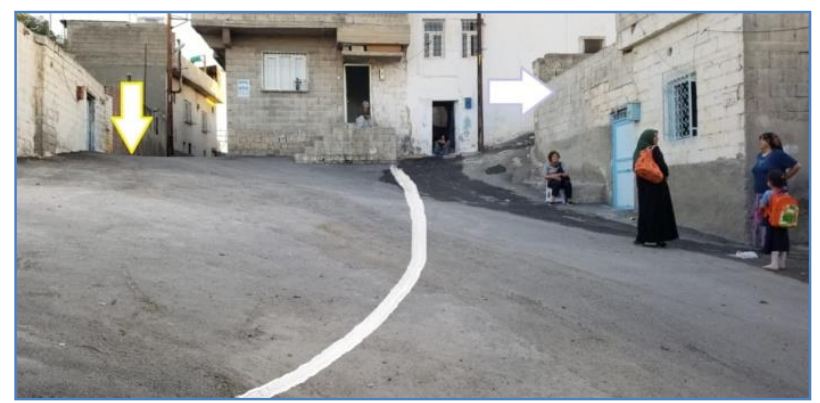

Photograph 18. The courtyard from North to South. Photographed by the Author, 2018. Left arrow points the hilltop. Right arrow points the landfill made after 1975 on the southwest side. And white line is the start of the Plaque settlement macroform.

\section{Conclusion}

Once property boundaries have been established anywhere on the surface of the earth, the place grows on top of itself, taking the initially formed property lines as its reference. In the plaque settlements determined, for thousands of years, similar patterns of plaque plans have been formed and the original settlement pattern is retained and plaque plan traces are visible in the urban pattern of today.

The plaques provide a variety of data and characteristics concerning the macroform and pattern of settlements and the layout of agricultural lands and support systems in the period in which they were made. These are the spatial planning and design principles of that land regime. The plaques also incorporate records of entitlement, topographical information and geographical thresholds. Because the plaques show geographical references, they are thought to have been created in accordance with a need for a spatial narration. That is why, Plaques exhibited in the museum are artisanal products with spatial dimensions. The Plaques also technically contain the same type of data and language of representation. They are spatial maps drawn on a 3-D model map. These plaques define land use decisions and cadastral parcel systematic of their time and geographical and topographical features.

The Akarçay Tepe plaques are also the symbols of a spatial whole formed by settlements in separate geographical locations. All the plaques studied appertain to settlements other than Akarçay Tepe: Birecik, Yeşilözen and Nizip. However these spatial plans and maps are developed in line with common social consent and a shared justification of spatial representation.

The community that produced the plaques acted in the knowledge that partition and sharing of land constitutes the foundation of production and of the social order. The plaques were produced by planned decision, conscious choice and social consensus of a Pre-Pottery Neolithic 
Age early-sedentary community rooted in targets for specific aims and functions.

Production and productivity may be thought of as the ultimate motivation for making the plaques, since they are related as much to the limits or amounts of the area under ownership as to the quality of the soil. It is thought that ownership of land was regulated in the period when agriculture first began in order to ensure the continuity of the land regime - which still persists in the region today and to prevent conflicts over boundaries.

The social need of proof and control is achieved through mathematics, geometry and form. The spatial identity was created by a 3-D model map through the arrangement of built-up areas and land. As a system that constitutes the basis of spatial planning, the plaques must have met a need to define, practice and perpetuate the level of development achieved by the community and a systematic order for agricultural production and human habitation.

As Plaque plans register the spatial knowledge, one is led to think that there was an authority and order in this region at the time they were made. Borrell and Molist (2014) and Arimura and Suleiman (2015) have determined that the regions of Syria and the Levant, which are close to our region, constituted a single regional entity in the Neolithic Age. It is therefore considered necessary, from this stage onwards, to answer the questions of which settlements the other plaques pertain to, why the spatial plans for settlements of an extensive area were gathered at Akarçay Tepe as the result of another social consensus - and hence what the geopolitical status of this settlement was.

Schmidt (2002, 2007a and 2007b) affirms that Göbeklitepe could not have been made by disorderly bands of hunter-gatherers, that hundreds of people would have needed to be provided with food and shelter to work in the tasks of carving, excavation and construction, and that there must therefore have been human settlements in the region at the time. Besides describing the type and form of settlements in the Pre-Pottery Neolithic Age in which they were made, the plaques may be considered to provide evidence for understanding the relationship between Göbeklitepe or similar cult sites and human settlements of that Age.

For the discipline of urban planning, the plaques as an important archaeological discovery, display the first typomorphology of urbanization. They originate to the PrePottery Neolithic Age. Plaques resulted from a planned act of spatial intervention with cartographic knowledge during the process of the formation of pre-urban villages and define the relationship between agriculture and settlement areas. And, it is important to note that maps and spatial planning has been present and demanded since the early forms of human settlements. The plaque with Finger-Fluting detail represents that since the Palaeolithic Age, there is the need for creating, mapping and planning the land regime.

\section{Acknowledgements}

I would like to thank Prof. Dr. Mihriban Özbaşaran for allowing me to work and publish on the three incised plaques from PPN Akarçay Tepe. I am also grateful to Emine Özlen Eren, Umut Müftüoğlu, Prof. Dr. H .Çağatay Keskinok, Assoc. Prof. Dr. Özcan Altaban, Prof. Dr. Murat Güvenç, Prof. Dr. Mehmet Özdoğan, Ferhat Karagözlü, Cengiz Baykara, Celal Uludağ, Muhittin Çiçek, Oğuzhan Yıldırım, Zeynep Ergün, Mehmet Batur, Bernard Kennedy, the Süleyman Demirel University Faculty of Architecture Deanery and Office for their contributions to this study.

\section{REFERENCES}

Algaze, G., Breuninger, R., Knudstad, J. (1994). “The Tigris-Euphrates archaeological reconnaissance project: Final report of the Birecik and Charchemish Dam survey areas", Anatolica 20: 1-96.

Arimura, M., Balkan-Atlı, N., Borrell, F., Bucak, E., Cruells, W., Duru, G., Erim-Özdoğan, A., Ibáñez, J.J., Maede, O., Miyake, Y., Molist, M., Özbaşaran, M., (2000). "Akarçay Tepe Kazısı, 1999", in Tuna N., Öztürk J. and Velioğlu J. (Eds.). Ilısu ve Kargamış Baraj Gölleri Altında Kalacak Arkeolojik Kültür Varlıklarını Kurtarma Projesi 1999 Yılı Çalışmaları, ODTÜ-TAÇDAM, Ankara: 181-90.

Arimura, M., Suleiman, A. (2015). "A cultural unity in Northwestern Syria during the Neolithic, Tell Ain Dara III, a PPNB site in the Afrin Valley", Paléorient, Vol. 41, No. 2: 85-99.

Borrell, F., Molist, M. (2014). "Social Interaction at the End of the Pre-Pottery Neolithic B: an Inter-site Analysis in the Euphrates Valley", Cambridge Archeological Journal 24(2), 215-31.

Bozbay, H. (2009). Neolitik Dönem Akarçay Tepe Yerleşmesinde Küçük Buluntular Işı̆̆ında Zanaat Ürünleri. İstanbul Üniversitesi Sosyal Bilimler Enstitüsü. Arkeoloji AD Prehistorya Bilim Dalı.

Çelik, B. (2008). Arkeolojide Urfa (Arkeolojik Araştırmalar Işı̆̆ında Urfa), Şanlıurfa Valiliği İl Kültür ve Turizm Müdürlüğü Yayınları, Istanbul. ISBN 978975-585-992-7.

Eren, Ş.G. (2018a). Akarçay Tepe Teknik Raporu.

Eren, Ş.G. (2018b). "Akarçay Tepe Kartografyası" (06.05.2018) GAP Zirvesi, 2. Uluslararas1 Piri Reis DilTarih-Coğrafya Kongresi. 04-06 May 2018. Şanlıurfa.

Eren, Ş. G. (2018c). “Ancient Smart Cadastrate: Akarçay Tepe Cadastral Map”. (09.05.2018). 26th FIG Congress. Istanbul. Embracing our smart world where the 
continents connect: enhancing the geospatial maturity of societies. 06-11 May 2018.

Ersoy, M. (compiler) (2012). Kentsel Planlama. Ansiklopedik Sözlük. Ninova Yayıncılık Tic. Ltd. Şti.

Harmankaya, S. and Erdoğu, B. 2002. TAY - Türkiye Arkeolojik Yerleşmeleri 4a/4b: İlk Tunç Çağı, TASK Vakfı Yayınları, Takım ISBN 975-6637-08-0, Cilt ISBN 975-6637-09-9, İstanbul.

Nizip Development Plan 1984. Bank of Provinces. 2018.

Nowell, A. (2017). "Visual Cultures in the Upper Paleolithic". Cambridge Archaeological Journal 27 (4): 599-606. McDonald Institute for Archaeological Res.

Özbaşaran, M., Molist, M. (2006). “Akarçay Tepe 2005”. Anatolia Antiqua, Tome 14: 245-49.

Özbaşaran, M., Molist, M. (2007). “Akarçay Tepe, Orta Firat'ta Neolitik Döneme Ait Yeni Bir Yerleşme" in Mehmet Özdoğan, Nezih Başgelen (Eds). Anadolu'da Uygarlığın Doğuşu ve Avrupa'ya Yayılımı. Türkiye'de Neolitik Dönem: Yeni Kazılar, Yeni Bulgular, Arkeoloji ve Sanat Yayınları, İstanbul: 179-87.

Özbaşaran, M. (2008). “9000 Y1llık Bezemeli Kireçtaşları" in Euergetes, Prof. Dr. Haluk Abbasoğu'na 65. Yaş Armağanı, Vol. II, Suna-İnan Kıraç Akdeniz Medeniyetleri Araştırma Enstitüsü: 833-39.

Schmidt, K. (2002). The 2002 Excavations at Göbeklitepe (Southeastern Turkey) - Impressions from an Enigmatic Site. Neo-Lithics 2(2): 8-13.

Schmidt, K. (2007a). "Göbeklitepe” in N. Başgelen (Ed.), 12000 Yıl Önce Uygarlığın Anadolu'dan Avrupa'ya Yolculuğunun Başlangıcı Neolitik Dönem, Yapı Kredi Yayınlar1. Istanbul: 93-95.

Schmidt, K. (2007b). Taş Çağı Gizemli Kutsal Alanı Göbeklitepe En EskiTapınağı Yapanlar translated by R. Aslan. Arkeoloji ve Sanat Yayınları, İstanbul.

\section{Internet Sources:}

- "Göbeklitepe: The World's First Temple", Nov. 2008." Smithsonian.com [Date of access: 26.03.2018].

- Schmidt, Klaus. 08.07.2014. "What is Göbeklitepe?" TED Conference.

- http://tacdam.metu.edu.tr/akarcay-tepe (Balkan-Atl1, N., Özbaşaran, M. 2002. Akarçay Tepe, METU TACDAM) [Date of access: 05.06.2017].

- http://www.bireciktso.org.tr/tr/foto-galeri/eskiresimlerde-birecik/ [Date of access: 19.01.2018]

- ESRI Online Topographic Map. 2018.

\footnotetext{
${ }^{1}$ Geostamps - registered by Dr. Şirin Gülcen Eren with the Ministry of Culture and Tourism of the Republic of Turkey on 08.02.2018 (Registration no. 2018/61).
} 